\title{
SIGNIFICANT FINANCIAL AND ECONOMIC RISK FACTORS IN COASTAL LAND RECLAMATION PROJECTS
}

\author{
H.A.H.P. Perera ${ }^{1}$, B.A.K.S. Perera ${ }^{2}$ and Archchana Shandraseharan ${ }^{3}$
}

\begin{abstract}
The demand for land required for construction and development has been rapidly increasing over the past 30 years in the global context because of population growth, especially in coastal cities. Therefore, coastal land reclamation (CLR) has drawn attention both internationally and regionally. However, CLR projects are complex and costly and, therefore, are often associated with numerous risks. Although risk management in CLR projects has been the focus of few past studies, they have not specifically focused on financial and economic risks. This study, therefore, aimed to identify the most significant financial and economic risk factors present in CLR projects to enable the management of those risks. The required empirical data were collected by conducting a two-round Delphi survey, comprising expert interviews and a questionnaire survey. The collected data were analysed using content and descriptive statistics. The results revealed 13 significant financial and economic risk factors of CLR projects. Quality of sand and soil was identified as the most important risk factor of CLR projects. Delayed payment, unpredictable safety and security conditions of the country, dredging volume and defaulting contractors and subcontractors were identified in the next top four ranking in this study.
\end{abstract}

Keywords: Coastal land reclamation; Financial and economic risk factors; Risk management, Construction industry

\section{INTRODUCTION}

Construction industry is prone to high risks because its complex and dynamic project environments cause uncertainties and risks (Mhetre et al., 2016). Most of the risks present in the industry, which can occur at various stages of the project life cycle, are dynamic and linked to stakeholder interests (Wang et al., 2016). These distinctive characteristics of the industry have made it risky. Various methods can be used to classify the risks of construction projects (Siraj and Fayek, 2019) into several categories (Siraj and Fayek, 2019; Lee and Schaufelberger, 2014). Almost all past studies have identified financial and economic risks as the two most significant types of risks present in construction projects (Chaudry and Iqbal, 2013). Financial and economic risks are significant because of their negative impact on cash flow, and project viability and profitability (Xenidis and Angelides, 2005). These risks often cause difficulties to construction companies or can even make them become bankrupt (Chen et al., 2010). In many developing countries,

\footnotetext{
${ }^{1}$ Department of Building Economics, University of Moratuwa, Sri Lanka, hashan.pubudu.95@gmail.com

${ }^{2}$ Department of Building Economics, University of Moratuwa, Sri Lanka, kanchana@uom.lk

${ }^{3}$ Department of Building Economics, University of Moratuwa, Sri Lanka, archchanas@uom.lk
} 
cash flow issues and financial deficiencies have led to underdevelopment and poor performance of the construction industry (Ghoddousi and Hosseini, 2012). Therefore, financial and economic risks that are significant in the construction industry will have a huge impact on the success of construction projects in terms of time, cost, and quality (Perera et al., 2020). Perera et al. (2020) emphasised that in the construction industry, systematic management of financial and economic risks is important. The importance of identifying the financial and economic risk factors in coastal land reclamation (CLR) projects is discussed below.

In recent years, land has been reclaimed to meet the demand for residential land in coastal and inland areas. Over the past 30 years, land demand in both inland and coastal areas have increased significantly (Sengupta et al., 2018). The growth of the population and expansion of cities, especially coastal cities, have brought pressure on land through construction and development activities (Tan et al., 2005). Maryati (2012) stated that CLR, which addresses human needs, has to be well managed in terms of material, social and economic development. However, due to their complexity, CLR projects encounter many risks (Li et al., 2016). These risks, caused by external and internal factors, can delay the completion of the projects (Prankevich, 2016). A proper assessment of the risks should include the determination of their causes, probability of occurrence, and consequences (Bianchi et al., 2010). The purpose of this study was to improve the effectiveness of CLR by synthesising, analysing, and developing the effectiveness of the output of specific CLR projects considering their financial and economic risks (Yurchenko, 2017).

Several past studies have identified the risk factors in the construction sector (Iqbal et al., 2015; Perera et al., 2020; Siraj and Fayek, 2019). Some of them were on CLR in different countries (Sengupta et al., 2018; Yusup et al., 2015). However, only few studies have focused on risk management in CLR projects (Yurchenko et al., 2019). The literature focussing on the financial and economic risks present in CLR projects is scarce. Therefore, this study aimed to identify the financial and economic risk factors that are significant in CLR projects.

\section{LITERATURE REVIEW}

\subsection{CONSTRUCTION RISKS}

Even though the term "risk" has no universal definition (Wang, 2018), different authors have provided definitions to it in different ways (Hansson, 2012; Hansson, 2017). A risk is defined as a probability, which excludes the events whose probability of occurrence cannot be determined correctly (Hansson, 2017). It is "uncertain" because although it indicates a danger, only its probability of occurrence can be specified (Zander, 2010). A risk can be defined using its probability and uncertainty (Aven, 2011). Risks in construction refer to events that can have an impact on project objectives at any stage of the project life cycle (Makombo, 2012). From the start to the completion of a project, and even during its operational phase, risks are present in every construction project, irrespective of the nature, complexity, size, and location of the project (Siraj and Fayek, 2019). 


\subsection{FINANCIAL AND ECONOMIC RISKS}

Financial risks are among the most influential factors influencing construction projects (Budde, 2020). The close connection between the operation of a construction organization and performance of economic and financial institutions is also a risk associated with construction projects (Fernando et al., 2017). The financial and economic risks of construction require construction project managers to manage time and the relationship between quality and cost in order to meet customer needs effectively (Kolhatkarl and Dutta, 2013). Therefore, a key factor that contributes to the success of a company is the prevention of financial risks (Chen et al., 2010). Thus, in this study, special emphasis was placed on the management of financial and economic risks. In this study, the term financial and economic risks referred to the combination of financial risks and economic risks which found in the literature, complying to the definition of "group of risks affecting the delivery of the project within the determined budget". The prevention of financial and economic risks is important to ensure the success of construction projects (Platon et al., 2014). In many developing countries, financial deficits and cash flow problems have exacerbated the underdevelopment and underperformance of their construction industries (Ghoddousi and Hosseini, 2012). Therefore, many researchers have identified financial and economic risks as the most significant risks commonly present in the construction industries of developing economies (Iqbal et al., 2015). Table 2 presents the literature review findings on financial and economic risk factors of construction projects.

\subsection{RISKS IN CLR PROJECTS}

Although the development of new islands through land reclamation has reaped several benefits, particularly in Asia and the Middle East, the development of global coastal areas can place the entire ecosystem of coastlines at risk (Chee et al., 2017). CLR causes a large-scale human disturbance to natural ecosystems, and it has already made negative impacts on the environment and ecosystems in coastal areas (Wang et al., 2016). Although the pollution caused by CLR can be controlled to a certain extent, its ecological and environmental impact cannot be rectified (Nadzir et al., 2014). Similarly, although intertidal reclamation can provide huge economic benefits, it changes local hydrodynamics (Jiao et al., 2006) because of the pollution caused by the reclamation material it releases (Naser, 2011). Land-ocean interactions are directly affected by land reclamation making an impact on the vegetation assessment and habitat distribution of coastal wetlands (Suzuki, 2003). The common risks of CLR include the changes in the domestic and foreign economic environments, which will determine the exchange rate of the stock market, reduce the exchange rates and purchase price of agricultural products, and increase the discount rates (Yurchenko et al., 2019). Production, financial, investment, and market risks are the four types of risks present in CLR projects (Yurchenko, 2017).

\subsection{NEED FOR IDENTIFYING FINANCIAL AND ECONOMIC RISK FACTORS OF CLR PROJECTS}

Rapid urbanisation has increased the population and the number of megacities, and expanded the related cities (Tan et al., 2005). Land in coastal cities has developed because of rapid and extensive urbanisation, which has exerted heavy pressure on the land (Li et al, 2016; Tan et al., 2005). Meanwhile, reclamation of land, commonly referred to as reclamation, is the process of creating new vacant land from the seabed or a riverbed. 
Thus, rapid economic development and the resulting urbanisation have led to CLR projects. CLR has played a significant role in the urban development of many developing countries, which have large populations. However, like other constructions, CLR has several risk factors, which hinder their success (Yurchenko, 2017). Financial and economic risks are important in the construction industry because they would have a significant impact on the success of construction projects (Pheng and Hou, 2019). Several past studies have addressed financial and economic risk management in the construction sector (Chen et al., 2010; Perera et al., 2020). CLR is one of the most significant types of construction. Any country can benefit from CLR. Few past studies have focused on the importance and implementation of land reclamation projects in inland and coastal areas (Sengupta et al., 2018; Yusup et al., 2015). Although few studies have focused on risk identification in CLR projects, very few of them has focused on financial and economic risk factors present in those projects. Understanding the impacts of reclamation is important to protect national economies (Mostafa, 2012). Thus, this study identified the financial and economic risk factors that are significant in CLR projects.

\section{METHODOLOGY}

Although a qualitative study is convenient to identify the risks associated with a project, researchers do not recommend that type of study because the collected data would be subjective and dependent on linguistic variables, consequently leading to imprecise outcomes (Islam and Nepal, 2016). This study, therefore, adopted the Delphi technique, a quantitative approach, to determine the financial and economic risk factors that are significant in CLR projects. The Delphi technique is suitable for risk-based construction studies owing to its self-validating mechanism (Perera et al., 2014). Literature does not mention the ideal number of rounds required for the Delphi process (Aghimien et al., 2020). However, in most Delphi studies on construction and management, a consensus can be reached after the second or third round (Ameyaw et al., 2016). In this study also, a consensus on the subject matter was reached after the second round. Due to the limited time and the possibility of reaching the professionals, data collection was done within the Sri Lankan context only.

\subsection{DELPHI ROUND 1}

Delphi Round 1 of this study focused on identifying the financial and economic risk factors applying to CLR projects. Table 1 presents the details of the respondents of the two Delphi rounds. In this round, questionnaires were distributed among 75 prospective respondents and 61 completed questionnaires were received.

Respondents were requested to validate for CLR projects, the 48 financial and economic risk factors identified from the literature which are generally considered in the construction industry (refer Table 2). They could also add new risk factors. The factors that received a score above $80 \%$ were validated for CLR projects. 
Table 1: Details of respondents of Delphi rounds 1 and 2

\begin{tabular}{|c|c|c|c|c|c|c|c|c|c|c|c|c|c|c|}
\hline \multirow{3}{*}{ Designation } & \multicolumn{7}{|c|}{ Delphi Round 1} & \multicolumn{7}{|c|}{ Delphi Round 2} \\
\hline & \multicolumn{4}{|c|}{ Y1 } & \multicolumn{3}{|c|}{ Y2 } & \multicolumn{4}{|c|}{ Y1 } & \multicolumn{3}{|c|}{ Y2 } \\
\hline & $\frac{0}{3}$ & ڤิ & กั่ & $\stackrel{2}{x}$ & $\stackrel{19}{\longrightarrow}$ & ค่ & $\frac{10}{3}$ & $\frac{n}{3}$ & فิ & 苚 & $\stackrel{n}{\wedge}$ & $\stackrel{n}{9}$ & in & $\frac{10}{3}$ \\
\hline Quantity Surveyor & 7 & 5 & 4 & 3 & 13 & 2 & 4 & 7 & 5 & 4 & 3 & 13 & 2 & 4 \\
\hline Engineer & 6 & 8 & 2 & 6 & 17 & 3 & 2 & 6 & 6 & 2 & 6 & 17 & 1 & 2 \\
\hline $\begin{array}{l}\text { Construction } \\
\text { Manager }\end{array}$ & 5 & 2 & 3 & 2 & 8 & 3 & 1 & 5 & 2 & 2 & 2 & 8 & 2 & - \\
\hline Town Planner & 4 & 2 & 1 & 1 & 6 & 2 & - & 4 & & 1 & & 6 & 1 & - \\
\hline Total & \multicolumn{4}{|c|}{61} & \multicolumn{3}{|c|}{61} & \multicolumn{4}{|c|}{58} & \multicolumn{3}{|c|}{58} \\
\hline
\end{tabular}

Y1: Experience in the Construction Industry and Y2: Experience in CLR Projects

\subsection{DELPHI ROUND 2}

Delphi Round 2 was conducted to identify the most significant risk factors among the financial and economic risk factors of CLR projects identified from Delphi Round 1. The questionnaires of Round 2 were distributed among the 61 respondents of Delphi Round 1. The number of completed questionnaires received was 58 (Rrefer Table 1). The respondents were asked to indicate the levels of the frequency of occurrence $(\alpha)$ and significance of the impact $(\beta)$ of each financial and economic risk factor. The severity index of each risk factor was thereafter calculated to rank the risk factors according to their levels of significance. Equation 01 was used to calculate the risk severity level of a risk factor and Equation 02 was used to identify the risk severity index.

$$
S_{j}^{i}=\alpha_{j}^{i} \beta_{j}^{i} \quad(01) \quad R S^{i}=\frac{\sum_{j=1}^{n} s_{j}^{i}}{n}
$$

where $\mathrm{n}=$ Number of responses, $S_{j}^{i}=$ Risk severity level of the $\mathrm{i}^{\text {th }}$ risk factor indicated by the $\mathrm{j}^{\text {th }}$ respondent, $\alpha_{j}^{i}=$ Frequency of occurrence of the $\mathrm{i}^{\text {th }}$ risk factor indicated by the $\mathrm{j}^{\text {th }}$ respondent, $\beta_{j}^{i}=$ Significance of the $\mathrm{i}^{\text {th }}$ risk factor indicated by the $\mathrm{j}^{\text {th }}$ respondent, and $R S^{i}=$ Risk Severity Index of the $\mathrm{i}^{\text {th }}$ risk factor.

\section{FINDINGS AND ANALYSIS}

\subsection{Financial ANd ECONOMic Risk FaCtors of CLR Projects}

Through the literature review, 48 financial and economic risk factors present in construction projects were identified. All the factors had scores exceeding $80 \%$. They were validated for CLR projects during Delphi Round 1. 23 of them were combined to form six factors. 10 new risk factors were also identified making the total number of identified risk factors 41 . Table 2 shows the financial and economic risk factors that were validated for CLR projects during Delphi Round 1; the newly identified risk factors are highlighted. 
Table 2: Financial and economic risk factors

\begin{tabular}{|c|c|}
\hline $\begin{array}{c}\text { Risk Factors Identified from The } \\
\text { Literature }\end{array}$ & $\begin{array}{c}\text { Risk Factors Validated for CLR Projects } \\
\text { During Delphi Round } 1\end{array}$ \\
\hline Financial status of the owner & Financial status of the owner \\
\hline Financial status of the contractor & Financial status of the contractor \\
\hline Regulatory issues & Regulatory issues \\
\hline Restrictions on repatriation of profits & Restrictions on repatriation of profits \\
\hline Defaulting contractors/ subcontractors & Defaulting contractors/ subcontractors \\
\hline Increased fuel prices & Increased fuel prices \\
\hline Delayed payments & Delayed payments \\
\hline Monopolies & Monopolies \\
\hline Insurance & Insurance \\
\hline Treasury policies & Treasury policies \\
\hline Unexpected long payback periods & Unexpected long payback periods \\
\hline Poor contract management & Poor contract management \\
\hline Inflation & Inflation \\
\hline Exchange rate fluctuations & Exchange rate fluctuations \\
\hline Uninterested recipients & Uninterested recipients \\
\hline Errors in feasibility and marketing surveys & Errors in feasibility and marketing surveys \\
\hline Taxation & Taxation \\
\hline Political interference & Political interference \\
\hline Strong competition & Strong competition \\
\hline Bankruptcy & Bankruptcy \\
\hline Unfair risk sharing & Unfair risk sharing \\
\hline $\begin{array}{l}\text { Lack of clarity in the allocation of } \\
\text { responsibilities }\end{array}$ & $\begin{array}{l}\text { Lack of clarity in the allocation of } \\
\text { responsibilities }\end{array}$ \\
\hline Reduced profitability & Reduced profitability \\
\hline Breach of contract & Breach of contract \\
\hline Lack of provisions for partial payments & Lack of provisions for partial payments \\
\hline
\end{tabular}

Changes in the market conditions

Lack of financial resources

Poor financial market

Uncertainties of economic development

Market demand

Changes in the market conditions

Financial failures

Lack of financial solvency

Credit risks

Material shortages

Labour and material price fluctuations

Extra costs for material \& equipment

Material shortage

purchases

Financial problems due to estimating errors

Underestimation of the construction cost

Financial problems due to document errors

Financial problems caused by estimating errors

Lack of funds to pay the concessionaire

Unavailability of funds

Cost overruns

Unavailability of funds

Budgetary issues

Unmanaged cash flows

Loans with variable interest rates

Interest rate fluctuations

Interest rate fluctuations 


\begin{tabular}{ll}
\hline \multicolumn{1}{c}{$\begin{array}{c}\text { Risk Factors Identified from The } \\
\text { Literature }\end{array}$} & \multicolumn{1}{c}{$\begin{array}{c}\text { Risk Factors Validated for CLR Projects } \\
\text { During Delphi Round 1 }\end{array}$} \\
$\begin{array}{ll}\text { Restrictions on repatriation of funds } \\
\text { Import/export restrictions }\end{array}$ & $\begin{array}{l}\text { Import/export restrictions } \\
\text { Political instability }\end{array}$ \\
Unpredictable safety \& security conditions of \\
the country \\
Deviations from planned works \\
Inappropriate social awareness \\
Environmental conditions \\
Effects of adverse weather \\
Acquisition issues \\
Social responsibilities \\
Quality of sand and soil \\
Dredging volume \\
\hline
\end{tabular}

\subsection{SIGNIFICANT FINANCIAL AND ECONOMIC RISK FACTORS OF CLR PROJECTS}

The significance of each of the shortlisted risk factors was identified at the end of Delphi Round 2, based on the severity index. As mentioned by El-Sayegh et al. (2018) and Hwang et al. (2017), financial and economic risk factors that had a severity index of 10 or higher were considered significant for CLR projects. Table 3 presents these risk factors, and their severity indices and rankings.

Table 3: Significant financial and economic risk factors of CLR projects

\begin{tabular}{lcccc}
\hline \multicolumn{1}{c}{ Risk Factor } & $\begin{array}{c}\text { RII - Risk } \\
\text { Occurrence }\end{array}$ & $\begin{array}{c}\text { RII - Risk } \\
\text { Impact }\end{array}$ & $\begin{array}{c}\text { Severity } \\
\text { Index }\end{array}$ & Rank \\
\hline Quality of sand and soil & 3.90 & 4.43 & 17.29 & 1 \\
Delayed payments & 3.96 & 3.55 & 14.06 & 2 \\
Unpredictable safety and security & 3.00 & 4.39 & 13.16 & 3 \\
conditions of the country & 3.57 & 3.42 & 12.19 & 4 \\
Dredging volume & 2.81 & 3.94 & 11.16 & 5 \\
Defaulting contractors/subcontractors & 2.81 & 3.90 & 10.87 & 6 \\
Financial problems caused by estimating & 2.97 & 3.55 & 10.77 & 7 \\
errors & 2.90 & 3.58 & 10.74 & 8 \\
Changes in the market conditions & 3.03 & 3.39 & 10.55 & 9 \\
Poor contract management & 2.97 & 3.45 & 10.23 & 10 \\
Material shortages & 3.48 & 2.97 & 10.16 & 11 \\
Reduced profitability & 2.65 & 3.80 & 10.06 & 12 \\
Deviations from planned works & 3.09 & 3.26 & 10.06 & 13 \\
\hline Unavailability of funds & & & & \\
Inappropriate social awareness & & & & \\
\hline
\end{tabular}

According to Table 3, among the 41 financial and economic risk factors of CLR projects, 13 are significant because their severity indices are 10 or higher. Of these 13 financial and economic risk factors, 8 were identified from the literature and the other 5 , which are 
highlighted in the table, were suggested by the experts during Delphi Round 1. Quality of sand and soil, unpredictable safety and security conditions of the country, dredging volume, deviations from planned works and inappropriate social awareness are the significant risk factors identified by the experts, which were ranked $1^{\text {st }}, 3^{\text {rd }}, 4^{\text {th }}, 11^{\text {th }}$ and $13^{\text {th }}$, respectively. Quality of sand and soil, which has the highest severity index of 17.29 , is the most significant risk factor. It is used to determine the construction method to be used in a CLR project. Payment delays are ranked $2^{\text {nd }}$ with a severity index of 14.06 . However, payment delays are ranked $1^{\text {st }}$ with regard to frequency of risk occurrence. Although some of the risk factors have received high rankings for frequency of occurrence or significance of their impacts, they are not significant according to their severity indices. Because a risk is generally calculated by multiplying its frequency by its impact, severity index will be more reliable than the frequency of occurrence or significance of the impact. The matrix presented in Figure 1 was plotted using the identified 41 risk factors to obtain a basic idea about the level of significance of each risk factor.

As Figure 1 demonstrates, only 13 factors can be identified as significant. The other factors are of average or high significance (Based on the cut-off adopted in this study which explained in the beginning of the sub-section 4.2). Therefore, all 41 factors have to be considered when managing financial and economic risks of CLR projects, with priority given to the most significant factors.

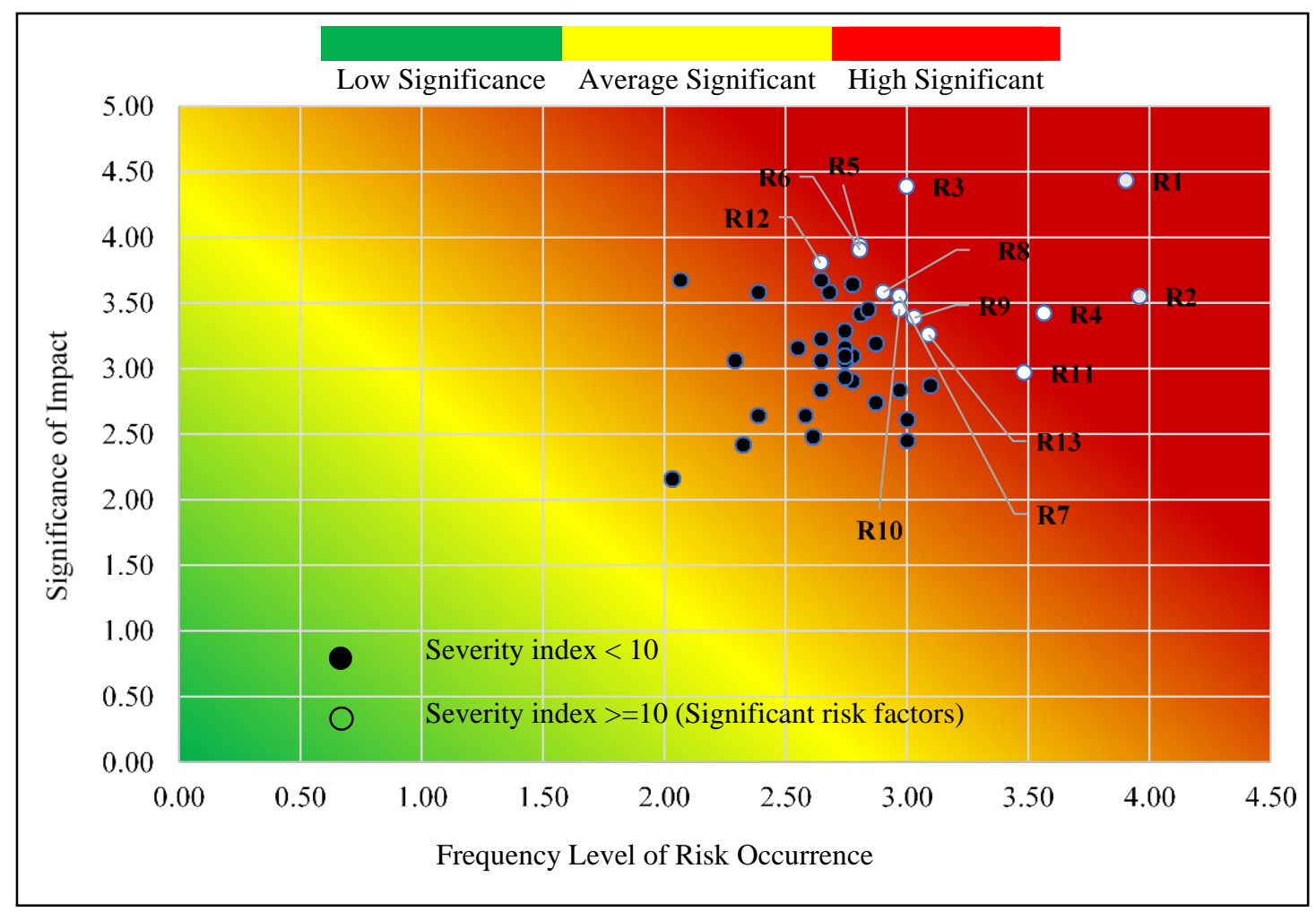

Figure 1: Risk matrix to identify the significant financial and economic risk factors of CLR projects 


\subsection{DETAILED ANALYSIS OF RISK FACTORS CONSIDERING THEIR FREQUENCY OF OCCURRENCE AND SIGNIFICANCE OF IMPACT}

Table 4 shows the factors that were ranked based on the RII of the frequency of risk occurrence and significance of impact. The factors that ranked high in their frequency of occurrence and significance of impact are highlighted in the table. Odeyinka et al. (2006) and El-Sayegh et al. (2018) used 2.70 and 3.10 as cut-off points to identify the most frequently occurring factors. Therefore, the factors that had a RII higher than 2.90 were selected as high frequency factors. El-Sayegh et al. (2018) and Hwang et al. (2017) used 3.8 and 3.37 as cut-off points to identify the level of significance of the factors based on the significance of their impact. Thus, the impacts of the factors with a RII higher than 3.40 were considered to be of high significance.

Although only 13 risk factors can be identified as significant based on their severity indices, according to the RII of frequency of risk occurrence, 14 factors are found to be significant. Environmental conditions, acquisition issues, effects of adverse weather and political instability are the factors that are not found significant according to their severity indices. Similarly, 15 factors can be identified as significant based on the RII of significance of their risk impact.

Table 4: Significance of the risk factors based on frequency of occurrence and significance of impact

\begin{tabular}{|c|c|c|c|c|c|}
\hline Rank & RII & $\begin{array}{c}\text { Risk Factors Ranked } \\
\text { Based on Frequency of } \\
\text { Occurrence }\end{array}$ & Rank & RII & $\begin{array}{c}\text { Risk Factors Ranked Based on } \\
\text { Significance of Impact }\end{array}$ \\
\hline 1 & 3.96 & Delayed payments & 1 & 4.43 & Quality of sand and soil \\
\hline 2 & 3.90 & Quality of sand and soil & 2 & 4.39 & $\begin{array}{l}\text { Unpredictable safety and security } \\
\text { conditions of the country }\end{array}$ \\
\hline 3 & 3.48 & $\begin{array}{l}\text { Deviations from pre- } \\
\text { determined planned works }\end{array}$ & 3 & 3.94 & $\begin{array}{l}\text { Defaulting contractors/ } \\
\text { subcontractors }\end{array}$ \\
\hline 4 & 3.57 & Dredging volume & 4 & 3.90 & $\begin{array}{l}\text { Financial problems arising from } \\
\text { estimating errors }\end{array}$ \\
\hline 5 & 3.10 & Environmental conditions & 5 & 3.80 & Unavailability of funds \\
\hline 6 & 3.09 & $\begin{array}{l}\text { Inappropriate social } \\
\text { awareness }\end{array}$ & 6 & 3.68 & Contractor's financial status \\
\hline 7 & 3.03 & Material shortages & 7 & 3.68 & Breach of contract \\
\hline 8 & 3.00 & $\begin{array}{l}\text { Unpredictable safety and } \\
\text { security conditions of the } \\
\text { country }\end{array}$ & 8 & 3.65 & Client's financial status \\
\hline 9 & 3.00 & Acquisition issues & 9 & 3.58 & Poor contract management \\
\hline 10 & 3.00 & Effects of adverse weather & 10 & 3.58 & Taxation \\
\hline 11 & 2.97 & Political instability & 11 & 3.58 & Bankruptcy \\
\hline 12 & 2.97 & Reduced profitability & 12 & 3.55 & Delayed payments \\
\hline 13 & 2.97 & $\begin{array}{l}\text { Changes in the market } \\
\text { conditions }\end{array}$ & 13 & 3.55 & Changes in the market conditions \\
\hline \multirow[t]{2}{*}{14} & 2.90 & Poor contract management & 14 & 3.45 & Errors in feasibility surveys \\
\hline & & & 15 & 3.45 & Reduced profitability \\
\hline
\end{tabular}


Contractor's financial status, breach of contract, client's financial status, taxation, bankruptcy, and errors in the feasibility survey are the factors identified based on the significance of their impact. Quality of sand and soil, which is the most significant risk factor according to its severity index, is ranked $2^{\text {nd }}$ according to its frequency of occurrence. However, quality of sand and soil is the most significant risk factor according to the significance of its impact and its severity index. Some of the other risk factors also has similar differences in their levels of significance determined based on the frequency of occurrence and significance of the impact.

\section{DISCUSSION}

Quality of sand and soil is the most significant risk factor in CLR projects. Because, quality of the sand and soil will affect the entire method of construction which will ultimately affect the financial and economic aspect of the project. Generally, delays in payments will cause serious cash flow problems, especially for contractors, which will have a destructive chain reaction on the procurement chain (Ansah, 2011). The impact of delayed payments was discussed by Perera et al. (2020), Siraj and Fayek (2019), Iqbal et al. (2015), and Platon et al. (2014). Iqbal et al. (2015) identified defaulting subcontractors as a significant risk factor of construction. In this study too, defaulting contractors/subcontractors were identified as a significant risk factor. Perera et al. (2020) stated financial problems caused by estimating errors and changes in the market conditions are the most significant risk factors faced in high-rise apartment construction. The results of the data analysis prove that these two risk factors may seriously affect land reclamation projects. According to the literature, reduced profitability is a significant risk factor of public construction projects (Platon et al., 2014). CLR projects are generally implemented by governments. Therefore, in CLR projects, the possibility of profit reduction is high. Through the literature review, many financial and economic factors were identified. Some of these factors are present almost in every construction project. Exchange rate fluctuations, interest rate fluctuations, and uncontrolled cash flows are the most common risk factors, confirmed by many past studies. (Iqbal et al., 2015; Siraj and Fayek, 2019). However, these factors had to be excluded from coastal projects because their impacts were small, or the possibility of their occurrence was low.

\section{CONCLUSIONS}

This study focused on identifying the financial and economic risk factors of CLR projects, which have received little attention in the past. At the end of Delphi Round 2, based on the cut-off level, 13 significant risk factors were identified, of which quality of soil and sand is the most significant risk factor. However, its frequency of occurrence is less than that of the $2^{\text {nd }}$ most significant risk factor, payment delays. Thus, the consideration of all 41 risk factors is important to ensure the success of CLR projects. It is recommended that awareness on the importance of contract management be promoted, being the most significant risk factor of CLR projects. Quality of sand and soil, unpredictable safety and security conditions of the country, dredging volume, deviations from planned works, and inappropriate social awareness are the new factors identified in this study. These risk factors of CLR projects can be taught in the relevant study programmes. The quantity surveyors should consider in their work, the financial and economic risk factors that this study focused on. The contribution made by the study is that the study will draw the attention of the construction industry to the importance of risk identification in CLR 
projects and to the financial and economic factors that are most significant in those projects. In addition, the study findings will help quantity surveyors to reduce the cost overruns of their projects by considering the financial and economic risk factors highlighted by the study. Moreover, since the demand for CLR is on the increase, the study findings will help CLR project stakeholders to ensure the viability of their future CLR projects. Several past studies have identified the financial and economic risk factors of construction projects in general without specifically focusing on CLR projects. Thus, the findings of this study make a theoretical contribution by providing a benchmark for the significance levels of the financial and economic risk factors of CLR projects. The study findings will also be a useful basis for further research to explore the strategies for financial and economic risk management in CLR projects. The assignment of those strategies to different stakeholders can also be investigated in future studies. One limitation of the study was that the required data were collected only from within Sri Lanka. This limitation will hinder the generalisation of the study findings. However, list of financial and economic factors summarised from this study can be generalised to the other developing countries. But significance order may vary from country to country. Further, this study can be referred by the developed countries as a basic to their investigation. The level of significance of each risk factor can differ from country to country depending on the geographical and weather conditions of the countries.

\section{REFERENCES}

Aghimien, D.O., Aigbavboa, C.O. and Oke, A.E., 2020. Critical success factors for digital partnering of construction organisations - A Delphi study. Engineering, Construction and Architectural Management, 27(10), pp. 3171-3188.

Ameyaw, E.E., Hu, Y., Shan, M., Chan, A.P.C. and Lee, Y., 2016. Application of Delphi method in construction engineering and management research: A quantitative perspective. Journal of Civil Engineering and Management, 22(8), pp. 991-1000.

Ansah, S.K., 2011. Causes and effects of delayed payments by clients on construction projects in Ghana. Journal of Construction Project Management and Innovation, 1(1), pp. 27-45.

Aven, T., 2011. On the new ISO guide on risk management terminology. Reliability Engineering and System Safety, 96(7), pp. 719-726.

Bianchi, M.L., Rachev, S.T., Kim, Y.S. and Fabozzi, F.J., 2010. Tempered infinitely divisible distributions and processes. Theory of Probability and its Application, 55(1), pp. 59-86.

Budde, N., 2020. [online]. How to Reduce Financial Risk on Construction Projects. Available from: https://www.levelset.com/blog/reduce-financial-risk-construction-projects-step-step-guide/ [Accessed 10 April 2021].

Chaudry, R. and Iqbal, K., 2013. Identification of risk management system in construction industry in Pakistan. Journal of Management in Engineering, 29(1), pp. 42-49.

Chee, S.Y., Othman, A.G., Sim, Y.K., Adam, A.N.M. and Firth, L.B., 2017. Land reclamation and artificial islands: Walking the tightrope between development and conservation. Global Ecology and Conservation, 12, pp. 80-95.

Chen, J.H., Yang, L.R., Su, M.C. and L.J.Z., 2010. A rule extraction-based approach in predicting derivative use for financial risk hedging by construction companies. Expert Systems with Applications, 37(9), pp. 6510-6514.

El-Sayegh, S.M., Manjikian, S., Ibrahim, A., Abouelyousr, A. and Jabbour, R., 2018. Risk identification and assessment in sustainable construction projects in the UAE. International Journal of Construction Management, 21(4), pp. 327-336.

Fernando, C., Hosseini, M.R., Zavadskas, E.K., Perera, B.A.K.S. and Rameezdeen, R., 2017. Managing the financial risks affecting construction contractors: Implementing Hedging in Sri Lanka. International Journal of Strategic Property Management, 21(2), pp. 212-224. 
Ghoddousi, P. and Hosseini, M., 2012. A survey of the factors affecting the productivity of construction projects in Iran. Technological and Economic Development of Economy, 18(1), pp. 99-116.

Hansson, S., 2012. A Panorama of the Philosophy of Risk. In: Roeser, S., Hillerbrand, R., Sandin, P. and Peterson, M. (eds) Handbook of Risk Theory. Springer, Dordrecht.

Hansson, S., 2017. Risk-knowledge, ignorance and values combined. In R. Peels (Ed.), In Perspectives on Ignorance from Moral and Social Philosophy (pp. 186-204). New York: Routledge.

Hwang, B., Shan, M. and Supa'at, N.N.B., 2017. Green commercial building projects in Singapore: Critical risk factors and mitigation measures. Sustainable Cities and Society, 30, pp. 237-247.

Iqbal, S., Choudhry, R.M., Holschemacher, K., Ali, A. and Tamosaitiene, J., 2015. Risk management in construction projects. Technological and Economic Development of Economy, 21(1), pp. 66-70.

Islam, M.S. and Nepal, M., 2016. A fuzzy-Bayesian model for risk assessment in power plant projects. Procedia Computer Science, 100, pp. 963-970.

Jiao, J., Wang, X. and Nandy, S., 2006. Preliminary assessment of the impacts of deep foundations and land reclamation on ground-water flow in a coastal area in Hong Kong, China. Hydrogeological Journal, 14(1), pp. 100-114.

Kolhatkarl, M. and Dutta, A., 2013. Financial risks and construction projects. International Journal of Application or Innovation in Engineering and Management, 2(11), pp. 235-239

Lee, N. and Schaufelberger, J.E., 2014. Risk management strategies for privatized infrastructure projects: Study of the build-operate-transfer approach in east Asia and the Pacific. Journal of Management in Engineering, 30(3), p. 05014001

Li, Y., Zhang, X., Zhao, X., Ma, S., Cao, H. and Cao, J., 2016. Assessing spatial vulnerability from rapid urbanization to inform coastal urban regional planning. Ocean and Coastal Management, 123(2016), pp. 53-65.

Makombo, H., 2012. The risk management framework for organisations dealing with construction project management in South Africa. MSc thesis. Prestoria: University of Pretoria.

Maryati, S., 2012. Land capability evaluation of reclamation Areain Indonesia coal mining using LCLP software. International Symposium on Earth Science and Technology, 6, pp. 465-473.

Mhetre, K., Konnur, B.A. and Landage, A.B., 2016. Risk management in construction industry. International Journal of Engineering Research, 5(1), pp. 153-155.

Mostafa, Y.S., 2012. Environmental impacts of dredging and land reclamation at Abu Qir Bay, Egypt. Ain Shams Engineering Journal, 3, pp. 1-15.

Nadzir, N., Ibrahim, M. and Monsoor, M., 2014. Impacts of coastal reclamation to the quality of life: Tanjung Tokong community, Penang. Procedia - Social and Behavioral Sciences, 153, pp. 159-168.

Naser, H., 2011. Effects of reclamation on microbenthic assemblages in the coastline of the Arabian gulf: A microcosm experimental approach. Marine Pollution Bulletin, 62(3), pp. 520-524.

Odeyinka, H., Lowe, J. and Kaka, A., 2006. An evaluation of risk factors impacting construction cash flow forecast. Journal of Financial Management of Property and Construction, 13(1), pp. 5-17.

Perera, B.A.K.S, Samarakkody, A.L. and Nandasena, S.R., 2020. Managing financial and economic risks associated with high-rise apartment building construction in Sri Lanka. Journal of Financial Management of Property and Construction, 25(1), 143-162.

Pheng, L.S. and Hou, L.S., 2019. The Economy and the Construction Industry. In: Construction Quality and the Economy, Management in the Built Environment. Springer, Singapore.

Platon, V., Frone, S. and Constantinescu, A., 2014. Financial and economic risks to public projects. Procedia Economics and Finance, 8, pp. 204-210.

Prankevich, D.A., 2016. Popular methods for assessing the effectiveness of IT projects. Progressive Technologies and Economics in Mechanical Engineering: Proceedings of the VII All-Russian Scientific and Practical Conference for students and students, 1, pp. 395-397.

Sengupta, D., Chen, R. and Meadows, M.E. 2018. Building beyond land: An overview of coastal land reclamation in 16 global megacities. Applied Geography, 90, pp. 229-238.

Siraj, N. and Fayek, A., 2019. Risk identification and common risks in construction: Literature review and content analysis. Journal of Construction Engineering and Management, 145(9), 1-13. 
Suzuki, T., 2003. Economic and geographic backgrounds of land reclamation in Japanese ports. Marine Pollution Bulletin, 47, pp. 226-229.

Tan, M., Li, X., Xie, H. and Lu, C., 2005. Urban land expansion and arable land loss in China - A case study of Beijing-Tianjin-Hebei region. Land Use Policy, 22(3), pp. 187-196.

Wang, M., 2018. Impacts of supply chain uncertainty and risk on the logistics performance. Asia Pacific Journal of Marketing and Logistics, 30(3), pp. 689-704.

Wang, T., Wang, S., Zhang, L., Huang, Z. and Li, Y., 2016. A major infrastructure risk-assessment framework: Application to a cross-sea route project in China. International Journal of Project Management, 34(7), pp. 1403-1415.

Xenidis, Y. and Angelides, D., 2005. The financial risks in build-operate-transfer projects. Construction Management and Economics, 23, pp. 431-441.

Yurchenko, I., 2017. Automatization of water distribution control for irrigation. International Journal of Advanced and Applied Sciences, 4(2), pp. 72-77.

Yurchenko, I., Vanzha, V., Bandurin, M., Volosukhin, V. and Bandurina I., 2019. Risk assessment of land reclamation investment projects. In Proceedings of the International Conference Communicative Strategies of Information Society, pp. 216-221.

Yusup, M., Arshad, A.F. and Abdullah, Y.A., 2015. Coastal land reclamation: Implication towards development control system in West Malaysia. Environment Behaviour Proceedings Journal, 1(1), pp. 354-361.

Zander, J., 2010. The Application of the Precautionary Principles in Practice. UK: Cambridge University Press. 